\title{
Front Matter: Volume 6874
}

, "Front Matter: Volume 6874," Proc. SPIE 6874, High Energy/Average Power Lasers and Intense Beam Applications II, 687401 (11 March 2008); doi:

$10.1117 / 12.796300$

EDIE Event: Lasers and Applications in Science and Engineering, 2008, San Jose, California, United States 


\section{PROCEEDINGS OF SPIE}

\section{High Energy/Average Power Lasers and Intense Beam Applications II}

Steven J. Davis

Michael C. Heaven

J. Thomas Schriempf

Editors

21-22 January 2008

San Jose, California, USA

Sponsored and Published by

SPIE

Volume 6874 
The papers included in this volume were part of the technical conference cited on the cover and title page. Papers were selected and subject to review by the editors and conference program committee. Some conference presentations may not be available for publication. The papers published in these proceedings reflect the work and thoughts of the authors and are published herein as submitted. The publisher is not responsible for the validity of the information or for any outcomes resulting from reliance thereon.

Please use the following format to cite material from this book:

Author(s), "Title of Paper," in High Energy/Average Power Lasers and Intense Beam Applications II, edited by Steven J. Davis, Michael C. Heaven, J. Thomas Schriempf, Proceedings of SPIE Vol. 6874 (SPIE, Bellingham, WA, 2008) Article CID Number.

ISSN 0277-786X

ISBN 9780819470492

Published by

SPIE

P.O. Box 10, Bellingham, Washington $98227-0010$ USA

Telephone +1 3606763290 (Pacific Time) · Fax +1 3606471445

SPIE.org

Copyright (c) 2008, Society of Photo-Optical Instrumentation Engineers

Copying of material in this book for internal or personal use, or for the internal or personal use of specific clients, beyond the fair use provisions granted by the U.S. Copyright Law is authorized by SPIE subject to payment of copying fees. The Transactional Reporting Service base fee for this volume is $\$ 18.00$ per article (or portion thereof), which should be paid directly to the Copyright Clearance Center (CCC), 222 Rosewood Drive, Danvers, MA 01923. Payment may also be made electronically through CCC Online at copyright.com. Other copying for republication, resale, advertising or promotion, or any form of systematic or multiple reproduction of any material in this book is prohibited except with permission in writing from the publisher. The CCC fee code is 0277-786X/08/\$18.00.

Printed in the United States of America.

Publication of record for individual papers is online in the SPIE Digital Library.

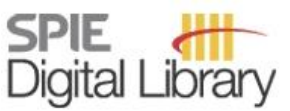

SPIEDigitalLibrary.org

Paper Numbering: Proceedings of SPIE follow an e-First publication model, with papers published first online and then in print and on CD-ROM. Papers are published as they are submitted and meet publication criteria. A unique, consistent, permanent citation identifier (CID) number is assigned to each article at the time of the first publication. Utilization of CIDs allows articles to be fully citable as soon they are published online, and connects the same identifier to all online, print, and electronic versions of the publication. SPIE uses a six-digit CID article numbering system in which:

- The first four digits correspond to the SPIE volume number.

- The last two digits indicate publication order within the volume using a Base 36 numbering system employing both numerals and letters. These two-number sets start with $00,01,02,03,04,05$, $06,07,08,09,0 \mathrm{~A}, 0 \mathrm{~B} \ldots \mathrm{OZ}$, followed by 10-1Z, 20-2Z, etc.

The CID number appears on each page of the manuscript. The complete citation is used on the first page, and an abbreviated version on subsequent pages. Numbers in the index correspond to the last two digits of the six-digit CID number. 


\section{Contents}

$\checkmark$ Conference Committee

\section{PLENARY SESSION}

687402 The long journey from idea to industrial success (Plenary Paper) [6874-26]

H. Schlüter, TRUMPF Inc. (USA)

\section{COIL AND EOIL}

687406 A method for comparison of computational fluid dynamic simulation and planar laser induced fluorescence images for a supersonic flowfield [6874-02]

T. J. Madden, C. A. Noren, Air Force Research Lab. (USA); L. Emmert, The Univ. of New Mexico (USA); M. C. Heaven, Emory Univ. (USA)

687407 Prediction of $\mathrm{I}^{2} \mathrm{P}_{1 / 2} \rightarrow{ }^{2} \mathrm{P}_{3 / 2}$ transition lineshapes from 3D, time dependent simulations of chemical oxygen-iodine laser (COIL) flowfields [6874-03]

T. J. Madden, Air Force Research Lab. (USA)

687408 Multi-pathway $\mathrm{I}_{2}$ dissociation model for COIL [6874-04]

V. N. Azyazov, P.N. Lebedev Physical Institute (Russia); M. C. Heaven, Emory Univ. (USA); S. Yu. Pichugin, P.N. Lebedev Physical Institute (Russia)

687409 A study on an all gas-phase iodine laser based on $\mathrm{NCl}_{3}$ reaction system [6874-06] T. Masuda, Keio Univ. (Japan); T. Nakamura, M. Endo, Tokai Univ. (Japan); T. Uchiyama, Keio Univ. (Japan)

COIL AND EOIL II

6874 OA Progress toward realization of a KW-class EOIL laser [6874-07]

A. E. Hill, Texas A\&M Univ. (USA) and Plasmatronics, Inc. (USA)

$6874 \mathrm{OB}$ Production of metastable singlet oxygen in the reaction of nitric oxide with active oxygen [6874-08]

W. T. Rawlins, S. Lee, S. J. Davis, Physical Sciences Inc. (USA)

$68740 \mathrm{C}$ Improved production of $\mathrm{O}_{2}\left(\mathrm{a}^{1} \Delta\right)$ in capacitively coupled radio-frequency discharges [6874-09]

J. W. Zimmerman, B. S. Woodard, Univ. of Illinois at Urbana-Champaign (USA);

J. T. Verdeyen, D. L. Carroll, T. H. Field, CU Aerospace (USA); W. C. Solomon, Univ. of Illinois at Urbana-Champaign (USA) 
6874 OD EOIL power scaling in a 1-5 kW supersonic discharge-flow reactor [6874-10]

S. J. Davis, S. Lee, D. B. Oakes, J. Haney, J. C. Magill, D. A. Paulsen, P. Cataldi,

K. L. Galbally-Kinney, D. VU, J. Polex, W. J. Kessler, W. T. Rawlins, Physical Sciences Inc. (USA)

\section{OPTICALLY PUMPED LASERS}

$6874 \mathrm{OE} \quad$ Hydrocarbon-free resonance transition 795-nm rubidium laser [6874-11]

S. S. Q. WU, Lawrence Livermore National Lab. (USA) and Univ. of California at San Diego (USA); T. F. Soules, R. H. Page, S. C. Mitchell, V. K. Kanz, R. J. Beach, Lawrence Livermore National Lab. (USA)

6874 OF Progress in alkali lasers development [6874-12]

B. V. Zhdanov, R. J. Knize, U.S. Air Force Academy (USA)

6874 OG Diode-pumped alkali vapor lasers for high power applications [6874-13]

J. Zweiback, General Atomics (USA); B. Krupke, WFK Lasers, LLC (USA); A. Komashko, General Atomics (USA)

\section{BEAM PROPAGATION}

$6874 \mathrm{OH} \quad$ Long-term stabilized two beam combination laser system with amplifiers using the phase controlled stimulated Brillouin scattering phase conjugate mirrors [6874-14]

H. J. Kong, J. W. Yoon, J. S. Shin, D. H. Beak, Korea Advanced Institute of Science and Technology (South Korea)

\section{GAS DISCHARGE LASERS}

6874 Ol Electra: durable repetitively pulsed angularly multiplexed KrF laser system (Invited Paper) [6874-16]

M. F. Wolford, M. C. Myers, J. L. Giuliani, J. D. Sethian, U.S. Naval Research Lab. (USA);

P. M. Burns, Research Scientific Instruments (USA); F. Hegeler, Commonwealth Technologies Inc. (USA); R. Jaynes, Science Applications International Corp. (USA)

6874 OK Recent developments in UV laser micromachining [6874-25]

R. Delmdahl, R. Pätzel, Coherent GmbH (Germany)

\section{POSTER SESSION}

$6874 \mathrm{OL} \quad$ High-intensity subpicosecond vacuum ultraviolet laser system [6874-21]

S. Kubodera, M. Kaku, Y. Taniguchi, M. Katto, A. Yokotani, Univ. of Miyazaki (Japan);

N. Miyanaga, K. Mima, Osaka Univ. (Japan)

6874 ON Techniques of single amplified high intensity ultra-short pulse laser system [6874-23]

J. Chen, K.-C. Chuang, Chung-Hua Univ. (Taiwan)

Author Index 


\title{
Conference Committee
}

\author{
Symposium Chairs \\ Henry Helvajian, The Aerospace Corporation (USA) \\ Friedrich G. Bachmann, Rofin-Sinar Laser GmbH (Germany) \\ Peter R. Herman, University of Toronto (Canada) \\ Donald J. Harter, IMRA America, Inc. (USA)
}

Program Track Chair

Gregory J. Quarles, VLOC (USA)

Conference Chairs

Steven J. Davis, Physical Sciences Inc. (USA)

Michael C. Heaven, Emory University (USA)

J. Thomas Schriempf, The Pennsylvania State University (USA)

Program Committee

David L. Carroll, CU Aerospace LLC (USA)

Jarmila Kodymova, Fyzikální Ústav (Czech Republic)

Timothy J. Madden, Air Force Research Laboratory (USA)

William E. McDermott, University of Denver (USA)

Wilson T. Rawlins, Physical Sciences Inc. (USA)

Session Chairs

1 COIL and EOIL

Steven J. Davis, Physical Sciences Inc. (USA)

2 COIL and EOIL II

Michael C. Heaven, Emory University (USA)

3 Optically Pumped Lasers

Michael C. Heaven, Emory University (USA)

4 Beam Propagation

Wilson T. Rawlins, Physical Sciences Inc. (USA)

5 Gas Discharge Lasers

David L. Carroll, CU Aerospace LLC (USA) 
Downloaded From: https://www.spiedigitallibrary.org/conference-proceedings-of-spie on 26 Apr 2023

Terms of Use: https://www.spiedigitallibrary.org/terms-of-use 